\title{
Analysis of seismic stability of shells of revolution using probabilistic methods
}

\author{
M. Danieli, J. Bloch \& I. Halperin \\ Department of Civil Engineering, \\ Ariel University Center of Samaria, Israel
}

\begin{abstract}
This work presents numerical methods of calculation of earthquake resistance of shells of revolution based on the application of the theory of random processes combined with the FEM. Probabilistic character of seismic effect is determined by using artificial accelerograms based on stochastic process. To illustrate the above methods of probabilistic analysis of seismic stability of structures, two real objects and one projected one are considered. Displacements, stresses, forces and moments resulting from the action of seismic load have been determined. Comparison of the results of calculation with those achieved using calculation of prescribed real accelerograms and building design codes have been made. Comparative analysis of the calculation results brings us to the conclusion that the difference between the results obtained using different methods can be quite significant. It means that when designing structures of the types of shells of revolution under consideration it is necessary to do calculations using all methods recommended by design codes as well as probabilistic methods.
\end{abstract}

Keywords: earthquake resistance, shell, revolution, FEM, probabilistic analysis.

\section{Introduction}

According to the existing building design codes (IS 413 [1], Eurocode 8 [2], UBC-1994 [3], etc.), the basic method for earthquake resistance analysis is the modal response spectrum analysis (Lindeburg [4], Chopra [5], etc). According to this method, the dynamic character of seismic effect is taken into account by means of various factors. Besides, in order to determine the response of building structures, it is recommended, for example, that calculations be done for recorded real, synthesized or simulated accelerograms (time history) geologic 
conditions as well as historic and archive data concerning the projected building site. Israeli standards (IS 413 [1]) consider such calculations as being additional; they do not replace principal calculations required by the standards. Since during an earthquake the vibrations of the base ground are non-stationary and chaotic which makes it impossible to form a judgment about the seismic stability of the whole structure by a response to some prescribed accelerograms, the approach based on application of the theory of random processes could be of certain interest (Housner [6], Bolotin [7], Newmark [8], Augusti et al. [9], etc.).

Accelerograms of an earthquake are considered to be non-stationary random processes represented by a product of a determined envelope and a stationary random process. The advantage of this approach consists in using generalized probabilistic characteristics of accelerograms (spectral densities and correlation functions) as initial data.

Equations of motion of the discrete model are given in Danielashvili et al. [10] within the framework of the FEM. They connect matrices of mass, damping and stiffness; vectors of structure joint displacement; and vector of space load distribution in joints. Seismic action in the form of non-stationary random vibrations of acceleration of the foundation is assumed to be the product of the determined envelope by stationary random process, the chart of its spectral density taking the form of a rectangle of calculation of the shell of revolution are given.

This paper uses artificial accelerograms of the ground. White noise ground acceleration time history has been modelled using simulation-based design methods (like Monte Carlo simulations) in accordance with the article by Ribakov and Agronovich [11].

To illustrate the above methods of probabilistic analysis of earthquake resistance of structures, two real objects and one projected one are considered. Displacements, stress, forces and moments resulting from the action of seismic load have been determined.

For comparative analysis of the calculation results, the calculation is also done for the prescribed real accelerograms El Centro Earthquake 1940 (Chopra [5]; etc.) and for the Israeli standards of earthquake resistance calculations (IS 413 [1]). These standards have been developed using Eurocode 8 [2] and uniform building code (UBC-1994[3]).

Analysis of seismic stability was carried out for all three buildings.

\section{Buildings and seismic situation}

\subsection{Buildings}

Ancient dome of a civil historical building (former mosque) in Ahaltsihe (Fig. 1) (Danieli et al. [12]).

The mosque built in the $18^{\text {th }}$ century. The building is situated in a seismic area in South Caucasia, Georgia. Its dome was built of locally manufactured thin bricks $(240 \times 240 \times 40 \mathrm{~mm})$ using a lime clay mortar. The dome dimensions are as follows: its span is $16.2 \mathrm{~m}$, rise $-8.0 \mathrm{~m}$, shell thickness $-0.6-0.8 \mathrm{~m}$. density $1.8 \mathrm{t} / \mathrm{m}^{3}$; Module of Deformation E= $=1.5 \times 10^{3} \mathrm{MPa}$. 
a

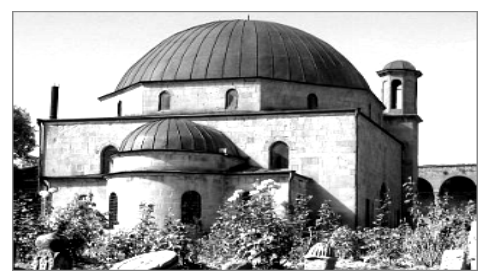

$\mathrm{b}$

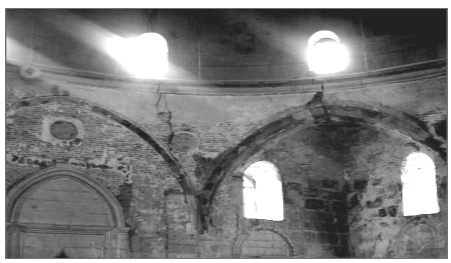

Figure 1: The civil historical building (former mosque) in Ahaltsihe. a - general view; b - cracks at the inner surface.

Building of the Museum of Defenders of Caucasian Passes near the city of Karachayevsk in the North Caucasia (Achvlediani [13]) (Fig. 2). The museum building is a reinforced concrete shell of revolution. Its walls are built in the form of a truncated cone with the height being $4.2 \mathrm{~m}$, lower base diameter $21.74 \mathrm{~m}$ and the upper base diameter $-19.65 \mathrm{~m}$. The construction coating has the form of a sphere segment with the rise being $1.6 \mathrm{~m}$. Thickness of the cone is $10 \mathrm{~cm}$ and of the sphere segment $-8 \mathrm{~cm}$.

Compressive strength for concrete - $30 \mathrm{MPa}$.

a

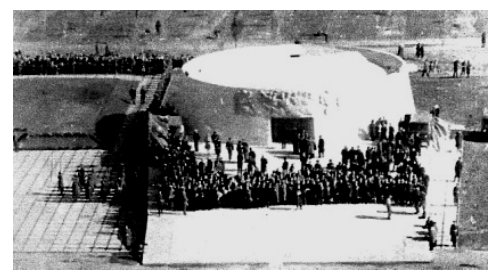

$\mathrm{b}$

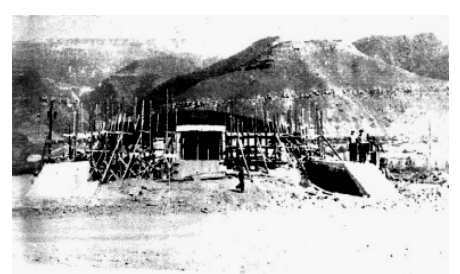

Figure 2: Building of the Museum of Defenders of Caucasian Passes. $\mathrm{a}$ - general view, $\mathrm{b}$ - view of the construction site.

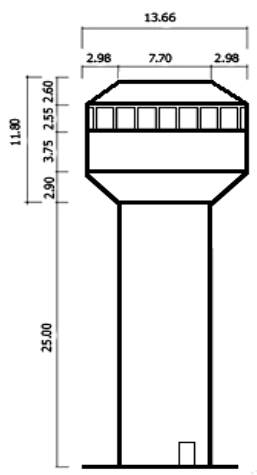

Figure 3: $\quad$ Water tower (project) (Halperin [14]).

The water tower (Fig. 3) construction is a coupled reinforced concrete shell of revolution consisting of a cylindrical shell (pillar) and a toroid shell (water tower). The height of the cylindrical shell is $25 \mathrm{~m}$, its external diameter is $7.7 \mathrm{~m}$ 
and its thickness is $20 \mathrm{~cm}$; the external diameter of the toroid shell is $13.7 \mathrm{~m}$, its internal diameter is $7.7 \mathrm{~m}$ and its thickness $-20 \mathrm{~cm}$. Its height is $11.8 \mathrm{~m}$. The bottom of the reservoir is at the mark of $25 \mathrm{~m}$. Volume of the water reservoir is $500 \mathrm{~m}^{3}$. Compressive strength for concrete $-30 \mathrm{MPa}$.

\subsection{Seismic situation}

The expected Richter magnitude for the Ahaltsihe area is $\mathrm{M}=7$ (Gabrichidze [15]). The mosque in Ahaltsihe, built in the $18^{\text {th }}$ century, was damaged by a series of major earthquakes: (a) in Akhalkalaki, Georgia, in 1899, at the distance of $45 \mathrm{~km}, \mathrm{M}=5.4$ (the magnitude has been estimated on the basis on the available descriptions of the earthquake consequences); (b) in Spitak, Armenia, in 1988, at $125 \mathrm{~km}, \mathrm{M}=6.9$; and (c) in Racha, Georgia, on April 29, 1991, at $125 \mathrm{~km}, \mathrm{M}=6.9$ (Gabrichidze [15]). This magnitude corresponds to the intensity $\mathrm{I}_{0}=9.5$ on the MSK-64 twelve-step scale. Several thousands of aftershocks were registered later on, during four months. Their magnitudes varied between $M=6.2$ and $\mathrm{M}=5.9$, being sometimes almost as powerful as the primary shock. The following map and chart illustrates this situation (Fig. 4).

a

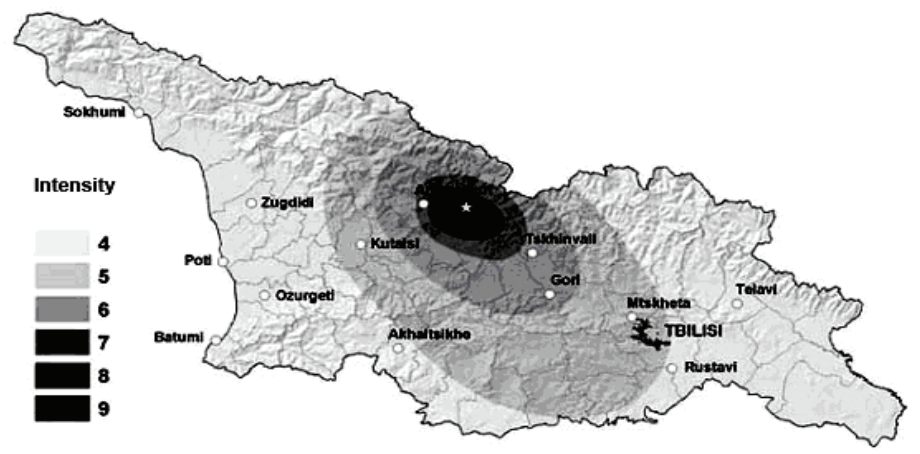

b

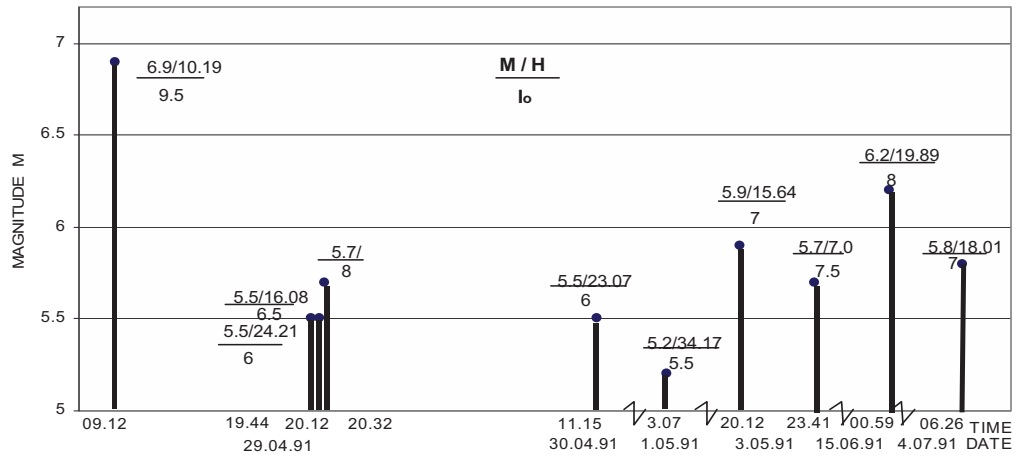

a - calculated earthquake intensity map; b - chart: primary shock and major secondary shocks (aftershocks) are shown. M - Richter magnitude; $\mathrm{H}$ - focus depth, km; $\mathrm{I}_{0}$ - intensity on MSK-64 scale.

Figure 4: Seismic situation caused by the earthquake in Racha, Georgia, between April 29 and July 04, 1991. 
Although the structure did not lose stability, the dome was damaged. Wide radial cracks appeared on the internal surface, mainly in relatively weak window areas (Fig. 1). At the bottom part they are as wide as $15-20 \mathrm{~mm}$. Tensile stresses in this area can be $0.045 \mathrm{MPa}$ due to the dome weight. The conservation project of the ancient dome is presented in the paper (Danieli et al. [12]). Results of linear (under static vertical and seismic loads) and non-linear (under static vertical and seismic loads) structural numerical analysis structure for ancient stone dome only and stone dome in interconnected stone-reinforced concrete structure presented, respectively, in (Danieli et al. [16]) and (Bloch et al. [17]).

The distance between the epicentre of the Racha earthquake and Karachaevsk is approximately $175 \mathrm{~km}$. Design ground acceleration for the Karachaevsk zone and the zone of the location of the water tower is $0.2 \mathrm{~g}$.

\section{Analysis of earthquake resistance of shells of revolution}

Analysis of seismic stability was carried out for all three buildings.

\subsection{Seismic action}

Seismic effect is prescribed as an artificial earthquake accelerogram borrowed from (Ribakov and Agronovich [11]). Modelling of artificial earthquake is done in the following way: a probability distribution function of a stochastic process or process realization should be assigned. The distribution is required for theoretical design and analysis. The simulation-based design methods (like Monte Carlo simulations) require generation of the excitation time histories.

At the first stage of this work an artificial white noise ground acceleration signal (earthquake) is generated using an originally developed algorithm implemented in MATLAB (High performance Numeric Computational and visualization software. User's Guide. The MathWorks Inc.) routines. The initial data for this algorithm is: the desired peak ground acceleration (PGA); the desired spectrum bandwidth (BW); and the duration of the earthquake $\left(t_{f}\right)$. The following parameters have been selected in this study: $P G A=0.3 \mathrm{~g}, \mathrm{BW}=10 \mathrm{~Hz}$ and $t_{f}=50 \mathrm{sec}$. These parameters were selected based on the available data on the ground acceleration for natural earthquakes including near field records. The proposed method and its program realization allow changing the parameters according to the required design conditions.

To use the data provided by Ribakov and Agranovich we have transformed them for the case of $\mathrm{PGA}=0.2 \mathrm{~g}$. A white noise artificial ground acceleration time history for PGA- $0.2 \mathrm{~g}, \mathrm{BW}=10 \mathrm{~Hz}$ are shown in Fig. 5a. Corresponding pseudo-acceleration response spectrum for damping rations 0,$02 ; 0,05 ; 0.1 ; 0.15$ is shown in Fig. 6a.

\subsection{Calculations of seismic stability}

Calculations of seismic stability were done on the basis of the STRAP program structural analysis and design software, version 8. Program STRAP uses Finite element calculation models. The basic method of the seismic analysis is the 

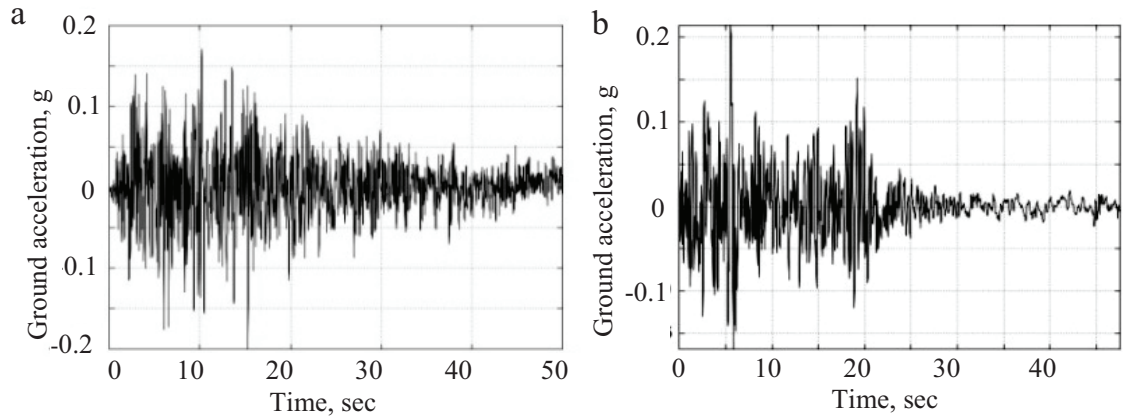

Figure 5: a - white noise artificial ground acceleration time history, PGA-0.2 g, BW=10 Hz; b - the ground acceleration of $1940 \mathrm{El}$ Centro Earthquake. Magnitude $\mathrm{M}=7$. Direction East-West.

modal response spectrum analysis. It consists of a dynamic analysis module and seismic analysis module. The dynamic analysis module analyses the modal shape of the model: solves for the natural frequencies and the corresponding mode shapes. The seismic analysis module calculates the earthquake response and the resulting moments and forces in the model based on the calculated mode shapes and code related factors. The mode shape analysis calculates " $n$ " different mode shapes.

Calculations are made in accordance with the modal spectrum response method and by using STRAP dynamic analysis module. The maximum response (deflection, base shear, etc) for each shape is calculated from a "Response spectrum". It is a graph which gives the acceleration as a function of the natural period, T, of the model. In order to use STRAP dynamic analysis module a response spectrum was generated for two earthquake ground accelerations: artificial earthquake and 1940 El-Centro earthquake. In order to generate response spectrum, a time history analysis for a large number of single-degreeof-freedom structures with different natural periods and damping ratios was carried out by MATLAB routines. The response spectrums were generated by finding the maximum deflection for each structure (Fig. 6 a,b). The spectrum data was transferred to STRAP as a data file.

An estimate of the maximum total response is made from the maximum calculated modal values- SRRS (Sum of Root of the Sum of the Square) method.

Analysis of seismic stability of the above buildings is done using a discrete model. Finite element calculation models for all three buildings, respectively, are shown in Fig. 7. As a result of the calculations according to the STRAP program for all three buildings considered in this paper, forms and periods of natural vibrations (mode shape), displacements, stresses, forces and moments were determined. The first three forms of natural vibrations (mode shape) for all three buildings, respectively, are shown in Fig. 8. 
a

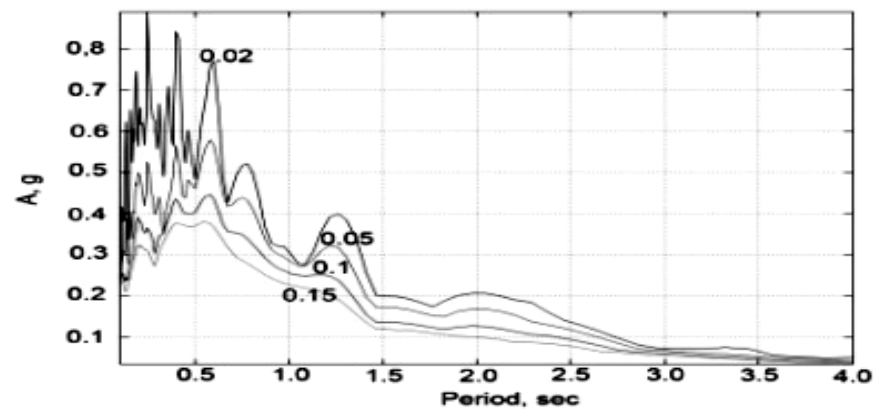

$\mathrm{b}$

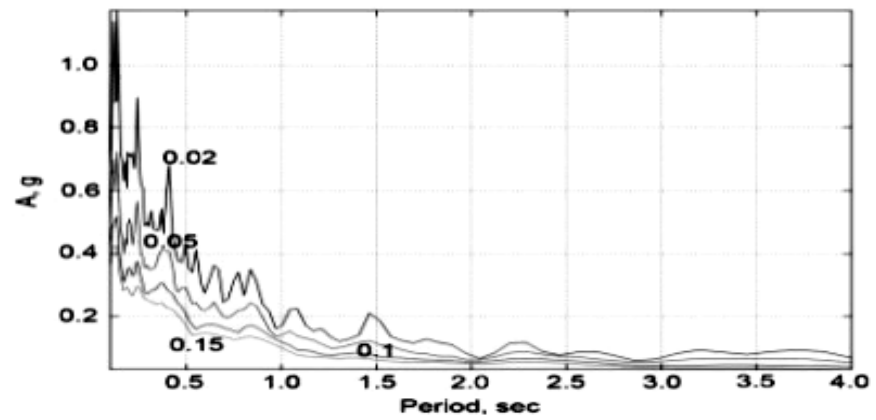

Figure 6: Pseudo-acceleration response spectrum. a - for artificial ground acceleration; b - for 1940 El Centro Earthquake ground acceleration. Numbers on the curves correspond to damping ratios.

a

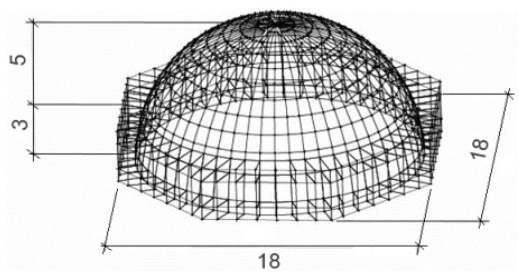

b
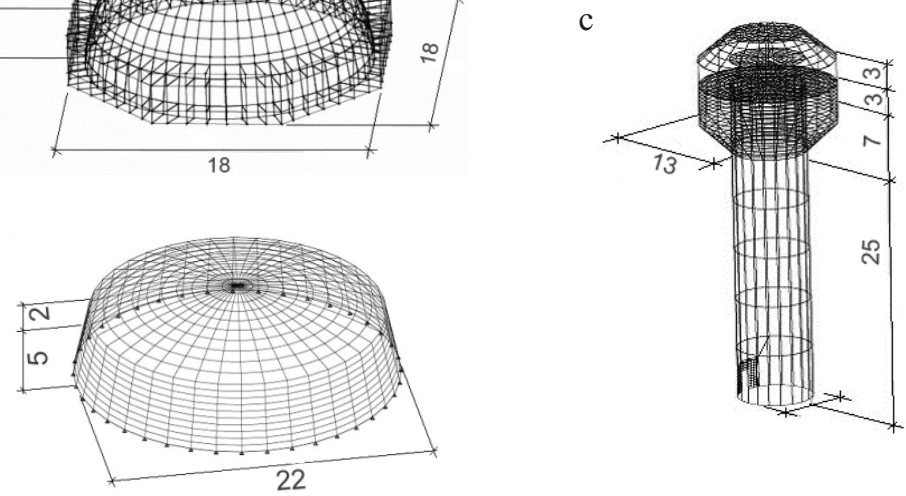

Figure 7: Finite element calculation models. a - ancient dome in Ahaltsihe; $\mathrm{b}$ - building of the Museum; c - water tower. 

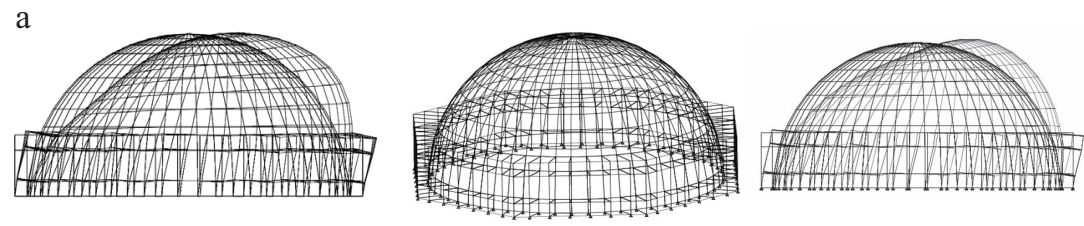

b
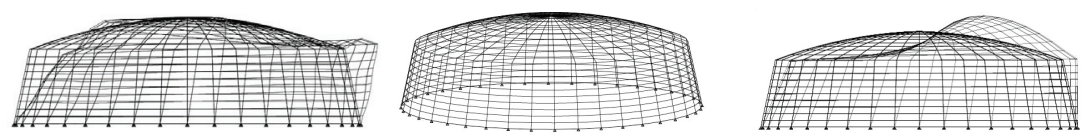

c
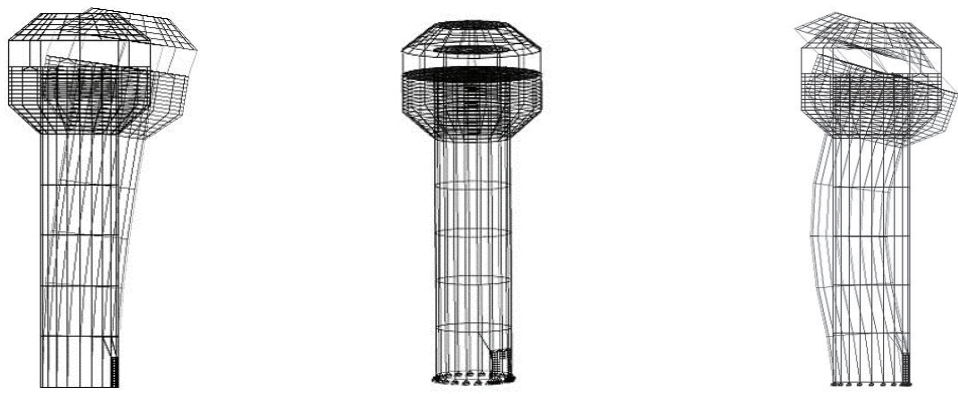

Figure 8: The first three forms of natural vibrations (mode shapes). a - ancient dome in Ahaltsihe; b - building of the Museum; c - water tower.

\subsubsection{Probabilistic analysis}

3.2.1.1 Calculation on the basis of the artificial earthquake accelerograms Seismic effect is prescribed as a white noise of the generated artificial ground acceleration (artificial earthquake accelerogram) (Fig. 5a). Corresponding pseudo-accelerations response spectrum for damping ratios 0.02 ; $0.05 ; 0.1 ; 0.15$ is shown in Figure 6 a. Some results of the calculations obtained are shown in Tables 1, 2 and 3.

\subsubsection{Comparative analysis}

3.2.2.1 Calculation on the basis of the earthquake EL Centro For comparative analysis, the seismic effect is prescribed as an accelerograms El Centro 1940; earthquake direction East-West (Fig.5b). Corresponding pseudoaccelerations response spectrum for damping ratios $0.02 ; 0.05 ; 0.1 ; 0.15$ is shown in Figure 6b. Some results of the calculations obtained are shown in Tables 1, 2 and 3.

3.2.2.2 Calculation on the basis of the Israeli standard Calculations are also done of all three shells of revolution according to the Israeli standard calculations using the modal response spectrum analysis method combined with the SRSS (in Square Root of the Sum of the Squares e) method (IS 413 [1]). Some results of the calculations obtained are shown in Tables 1, 2 and 3. 
Table 1: Dome in Ahaltsihe. Main results of structural analysis. Maximum values.

\begin{tabular}{|c|c|c|c|c|}
\hline \multirow[b]{2}{*}{ Parameters } & \multicolumn{3}{|c|}{ Seismic loads } & \multirow[b]{2}{*}{ Static loads } \\
\hline & $\begin{array}{l}\text { Artificial } \\
\text { earthquake }\end{array}$ & $\begin{array}{l}\text { EL Centro } \\
\text { earthquake }\end{array}$ & $\begin{array}{c}\text { IS- } 413 \\
1998\end{array}$ & \\
\hline $\begin{array}{l}\text { Periods of natural vibrations, s: } \\
\qquad \mathrm{T}_{1} ; \mathrm{T}_{2} ; \mathrm{T}_{3}\end{array}$ & \multicolumn{3}{|c|}{$0.082 ; 0.050 ; 0.049$} & \\
\hline $\begin{array}{l}\text { Max. displacement, mm } \\
\text { vertical, w } \\
\text { horizontal, u }\end{array}$ & $\begin{array}{l}0.27 \\
0.88\end{array}$ & $\begin{array}{l}0.16 \\
0.51\end{array}$ & $\begin{array}{l}0.13 \\
0.42\end{array}$ & $\begin{array}{l}1.89 \\
0.19\end{array}$ \\
\hline $\begin{array}{c}\text { Maximum stress, MPa } \\
\sigma_{\mathrm{Ny}}(+) / \sigma_{\mathrm{Ny}}(-) \\
\sigma_{\mathrm{Nx}}(+) / \sigma_{\mathrm{Nx}}(-)\end{array}$ & $\begin{array}{l}0.037 / 0.049 \\
0.012 / 0.082\end{array}$ & $\begin{array}{l}0.214 / 0.028 \\
0.007 / 0.047\end{array}$ & $\begin{array}{l}0.017 / 0.023 \\
0.005 / 0.039\end{array}$ & $\begin{array}{c}-/ 0.17 \\
0.02 / 0.15\end{array}$ \\
\hline $\begin{array}{l}\text { Earthquake direction: horizontal } \\
\text { Seismic zone factor }-\mathrm{Z} \\
\text { Site coefficient }-\mathrm{S} \\
\text { Seismic importance factor }-\mathrm{I} \\
\text { Reduction factor }-\mathrm{K} \\
\text { Damping ratio }-\zeta\end{array}$ & 0.1 & 0.1 & $\begin{array}{l}0.2 \\
1.2 \\
1.4 \\
3.5 \\
0.1\end{array}$ & \\
\hline
\end{tabular}

Table 2: Building of the museum. Main results of structural analysis. Maximum values.

\begin{tabular}{|c|c|c|c|c|}
\hline \multirow[b]{2}{*}{ Parameters } & \multicolumn{3}{|c|}{ Seismic loads } & \multirow[b]{2}{*}{ Static loads } \\
\hline & $\begin{array}{l}\text { Artificial } \\
\text { earthquake }\end{array}$ & $\begin{array}{l}\text { EL Centro } \\
\text { earthquake }\end{array}$ & $\begin{array}{l}\text { IS- } 413 \\
1998\end{array}$ & \\
\hline $\begin{array}{l}\text { Periods of natural vibrations, } \mathrm{s} \text { : } \\
\qquad \mathrm{T}_{1} ; \mathrm{T}_{2} ; \mathrm{T}_{3}\end{array}$ & \multicolumn{3}{|c|}{$0.0283 ; 0.0273 ; 0.0239$} & \\
\hline $\begin{array}{l}\text { Max. displacement, mm } \\
\text { vertical, } \mathrm{w} \\
\text { horizontal, u }\end{array}$ & $\begin{array}{l}0.04 \\
0.18\end{array}$ & $\begin{array}{l}0.02 \\
0.07\end{array}$ & $\begin{array}{l}0.01 \\
0.04\end{array}$ & $\begin{array}{l}3.630 \\
0.087\end{array}$ \\
\hline $\begin{array}{c}\text { Maximum stress, MPa } \\
\sigma_{\mathrm{Ny}}(+) / \sigma_{\mathrm{Ny}}(-) \\
\sigma_{\mathrm{Nx}}(+) / \sigma_{\mathrm{Nx}}(-)\end{array}$ & $\begin{array}{l}0.139 / 0.096 \\
0.121 / 0.346\end{array}$ & $\begin{array}{l}0.052 / 0.036 \\
0.045 / 0.129\end{array}$ & $\begin{array}{l}0.027 / 0.018 \\
0.026 / 0.067\end{array}$ & $\begin{array}{l}2.135 / 2.854 \\
2.309 / 1.221\end{array}$ \\
\hline $\begin{array}{l}\text { Earthquake direction: } \\
\text { horizontal } \\
\text { Seismic zone factor }-\mathrm{Z} \\
\text { Site coefficient }-\mathrm{S} \\
\text { Seismic importance factor }-\mathrm{I} \\
\text { Reduction factor }-\mathrm{K} \\
\text { Damping ratio }-\zeta\end{array}$ & 0.05 & 0.05 & $\begin{array}{c}0.2 \\
1.5 \\
1.2 \\
2 \\
0.05\end{array}$ & \\
\hline
\end{tabular}


Table 3: Water tower. Main results of structural analysis. Maximum values.

\begin{tabular}{|c|c|c|c|c|}
\hline \multirow[b]{2}{*}{ Parameters } & \multicolumn{3}{|c|}{ Seismic loads } & \multirow[b]{2}{*}{ Static loads } \\
\hline & $\begin{array}{c}\text { Artificial } \\
\text { earthquake }\end{array}$ & $\begin{array}{l}\text { EL Centro } \\
\text { earthquake }\end{array}$ & $\begin{array}{l}\text { IS- } 413 \\
1998\end{array}$ & \\
\hline $\begin{array}{l}\text { Periods of natural vibrations, } \mathrm{s} \text { : } \\
\qquad \mathrm{T}_{1} ; \mathrm{T}_{2} ; \mathrm{T}_{3}\end{array}$ & \multicolumn{3}{|c|}{$0.5688 ; 0.1562 ; 0.1333$} & \\
\hline $\begin{array}{l}\text { Max. displacement, mm } \\
\text { vertical, w } \\
\text { horizontal, u }\end{array}$ & $\begin{array}{l}5.56 \\
1.72\end{array}$ & $\begin{array}{c}9.55 \\
42.73\end{array}$ & $\begin{array}{l}15.94 \\
71.22\end{array}$ & $\begin{array}{c}9.97 \\
44.57\end{array}$ \\
\hline $\begin{array}{c}\text { Maximum stress, MPa } \\
\sigma_{\mathrm{Ny}}(+) / \sigma_{\mathrm{Ny}}(-) \\
\sigma_{\mathrm{Nx}}(+) / \sigma_{\mathrm{Nx}}(-)\end{array}$ & $\begin{array}{l}1.602 / 4.139 \\
1.584 / 0.628\end{array}$ & $\begin{array}{l}9.317 / 0.175 \\
1.398 / 1.174\end{array}$ & $\begin{array}{l}15.54 / 0.238 \\
2.331 / 1.596\end{array}$ & $\begin{array}{l}9.723 / 0.153 \\
1.459 / 1.029\end{array}$ \\
\hline $\begin{array}{l}\text { Earthquake direction: horizontal } \\
\text { Seismic zone factor }-\mathrm{Z} \\
\text { Site coefficient }-\mathrm{S} \\
\text { Seismic importance factor }-\mathrm{I} \\
\text { Reduction factor }-\mathrm{K} \\
\text { Damping ratio }-\zeta\end{array}$ & 0.05 & 0.05 & $\begin{array}{c}0.2 \\
1.5 \\
1.2 \\
5.5 \\
0.05\end{array}$ & \\
\hline
\end{tabular}

Remarks (Tables 1, 2, 3): "+"- tension; "-"- compression; "y"- meridian direction; " $\mathrm{x}$ "- ring direction.

\section{Discussion of the calculation results}

Comparative analysis of the calculation results (Tables 1, 2 and 3) brings us to the conclusion that the difference between the results obtained using different methods can be quite significant. Thus for the ancient dome and the shell of revolution of the museum artificial earthquake is more dangerous while for the water tower the earthquake EL Centro is more dangerous. It means that when designing structures of the types of shells of revolution under consideration it is necessary to do calculations using all methods recommended by design codes as well as probabilistic methods.

The above numerical data of the calculation (Tables 1 and 2) show a low level displacements as well as of stresses in respect of stresses of static loads for the two first shells of revolution of the cover of the ancient dome and reinforced shell revolution of the museum when they are affected by the most severe earthquakes. It shows that shells of revolution are highly effective and safe as far as their seismic stability is concerned.

At the same time, for the water tower (Table 3) displacements, especially horizontal displacements are significant and stresses of seismic action usually exceed the stresses of static loads. It demonstrates the high sensitivity of the water tower to seismic loads.

It should be stressed that Israeli standards (IS 413 [1]) do not consider shelltype constructions as an independent type of constructions which makes it difficult to select corresponding factors for them. Reduction factor " $\mathrm{K}$ " (factor of 
reduction of seismic load, structural types factor) is of special importance since it varies from 2 to 7 . That is why it is recommended to do research into determining this factor " $\mathrm{K}$ " and to single out shells of revolution into a separate group in standards for determining factor " $\mathrm{K}$ ". This recommendation is especially important due to the fact that shells of revolution are as a rule longspan structures.

There are more convenient conditions for water towers, however, for they compose an independent group for determination of the Reduction factor " $\mathrm{K}$ ". And this accounts for a relatively lesser discordance between the results of calculations obtained using various methods of analysis.

\section{Conclusions}

1. The above numerical data of the calculation show a low level of stresses and displacement of the shells of revolution of covers when affected by the most severe earthquakes which proves that the cover constructions in the form of shells of revolution are highly effective where their seismic stability is concerned.

2. When designing shells of revolution, it is recommended that calculations be done using all methods recommended by designers' standards including time history analysis and probabilistic methods.

3. We recommend that construction standards single out shell constructions as a separate group to make it easier to select true calculation factors, reduction factor $\mathrm{K}$ in particular. This conclusion is especially important due to the fact that shells of revolution are as a rule long-span structures.

\section{Acknowledgements}

Authors appreciate the assistance given by Dr. Y. Rybakov and Prof. G. Agranovich who provided the data for construction of accelerograms of artificial earthquakes. They also acknowledge Dr. G. Sirotin's contribution to preparing this paper for publication.

\section{References}

[1] Israeli Standard - 413. Design provisions for earthquake resistance of structures, Tel-Aviv, 1998 (in Hebrew).

[2] Eurocode 8 Design Provisions for Earthquake Resistance of Structures, 1993; 2000.

[3] Uniform Building Code. Structural Engineering Design Provisions, ch. 16, div. III - Earthquake Design, 1994.

[4] Lindeburg, M.R. Seismic design of Building Structures. Belmont, CA.

[5] Chopra, A.K. Dynamics of Structures, (2 ed.), Prentice Hall, N.J., 2001.

[6] Housner, G.W. Characteristics of strong motion earthquakes, Bull. Seismol. Soc. Am 37, pp.19-31, 1947. 
[7] Bolotin, V.V. Statistical Methods in Structural Mechanics, Holden-Day, San Francisco, 1969.

[8] Newmark, N. M. and Rosenblueth, E. Fundamentals of Earthquake Engineering, Prentice-Hall, Englewood Cliffs, N.Y, 1971.

[9] Augusti, G., Baratta, A. and Casciati, F. Probabilistic Methods in Structural Engineering, Chapman and Hall: London-New York, 1984.

[10] Danielashvili, M., at al. Analysis of earthquake resistance of reinforced shells of revolution using probabilistic methods. Spatial Structures of Buildings and Edifices, Moscow, pp.8-12, 1996 (in Russian).

[11] Ribakov, Y. and Agronovich, G. Design of Hybrid Base Isolation Systems with Passive Friction Dampers, Eur. Earthquake Eng. 3, pp. 48-56, 2007.

[12] Danieli (Danielashvili), M, Gabrichidze, G., Goldman, A. and Sulaberidse, O. Experience in restoration and strengthening of stone made ancient domes in seismic regions. Proc. of $7^{\text {th }}$ US National Conf. on Earthquake Engineering. Boston, MA, USA. Vol. II, pp. 1167-1175, 2002.

[13] Akhvlediani, N. V., Danielashvili , M. A., et al. Investigation, Design and Construction of Antiseismic Spatial Structures Based on the Theory of Limit Equilibrium. Proc. of the Int. Cong. of IASS “Theor. and Exp. Studies of Spatial Structures”. Moscow, Vol. 4, pp. 190-201, 1985.

[14] Halperin, Y. Water Tower, student's graduation work, Dep. of Civil Engineering, Ariel University Center of Samaria, Israel, 2009.

[15] Gabrichidze, G. (ed.) Engineering Analysis of the Racha Earthquake Consequences in Georgia, 1991, Metsnereba, Tbilisi, Georgia, 1996 (in Russian).

[16] Danieli (Danielsvilli), M., Aronchik, A., Bloch, J. Seismic safety of an ancient stone dome strengthened by an original method. Proc. of 13th World Conf. on Earthquake Eng. Vancouver, B.C., Canada, paper No 2789 (SD-R), 2004.

[17] Bloch, J., Aronchik, A., Danieli (Danielashvili), M. Ancient Stone Dome Strengthening in Seismic Regions by an Original Method and Non-Linear Stress-Strain Analysis Problems. Proc. of the $8^{\text {th }}$ US Nat. Conf. on Earthquake Eng. (8NCEE) San Francisco ,California, USA, paper No 31 (SD-R), 2006. 